\title{
The Effect of Working Capital Management and External Capital on Going Concern for Indonesian Small and Medium Enterprises
}

\author{
Widya Exsa Marita \\ Accounting Department, Faculty of Economics, Universitas Negeri Surabaya, Surabaya, Indonesia \\ widyaexsa18@gmail.com \\ Ika Permatasari \\ Accounting Department, Faculty of Economics, Universitas Negeri Surabaya, Surabaya, Indonesia \\ ikapermatasari@unesa.ac.id
}

Received: 09-02-2019

Revisied: 24-10-2019

Accepted: $31-10-2019$

\section{ABSTRACT}

This study aimed to examine the influence of working capital management and external capital ongoing concern of small and medium enterprises in Indonesia. This study used small and medium listed enterprises in Indonesia as a sample, which were included in the Pefindo- 25 index from the year 2009-2016. The results showed that working capital management had a negative effect on SME's going concern, while the external capital had a positive effect. This study had the implication for small and medium-sized issuers, which was they were expected to be able to accelerate the company's cash conversion cycle to improve working capital management so as to improve the sustainability of their business. In addition, they were expected to consider external capital as an alternative capital to increase competitiveness in the market.

Keywords: going concern, external capital, small and medium enterprises, working capital management,

How to cite: Marita, W. E., Permatasari, I. (2019). The Effect of Working Capital Management and External Capital on Going Concern for Indonesian Small and Medium Enterprises. Akrual: Jurnal Akuntansi, 11 (1): 21-35. doi: http://dx.doi.org/10.26740/jaj.v11n1.p21-35

\section{INTRODUCTION}

Since 2016 all countries in the world were experiencing a period of uncertainty. This unpredictable economic change would inevitably impact how Indonesian enterprises could sustain their lives. One type of business that was affected by this economic uncertainty was small and medium listed enterprises. The reason was that the small and medium-sized publicly-listed enterprises were companies that had a limited amount of assets, so they must be able to manage their operations with limited resources. Didonet et al. (2012) and Moss \& Stine (1993) stated that when economic uncertainty occurs, the business continuity of small and medium scale enterprises was the most affected.
The sustainability of business (going concern) was one of the main objectives of the establishment of a company (Sari, 2014). Normally, a company owner may not want the company he founded to go bankrupt. This makes the need for maximum thought and effort to deal with various problems that could threaten the sustainability of a business. As a form of this thinking, one of them was a large number of studies that discuss and examine more closely the topic of the sustainability of this business. However, it should be noted that most of the existing research examines and discusses how going concern was assessed by an auditor. Whereas the fact that there were some enterprises which in the previous year received 
going-concern opinion, but in the following year experienced problems that worried about the continuity of their business and eventually had to be forcefully delisted from the Indonesia Stock Exchange (IDX). This makes the going concern opinion of the auditor could not be guaranteed (Svanberg \& Öhman, 2014).

Cases like this had been experienced by PT. Citra Maharlika Nusantara Corpora Tbk in 2017, which in the previous year that was 2016, the auditor gave a going concern opinion, but in 2017 the company was forcibly delisted by the IDX. This forced delisting was carried out because the company was declared bankrupt. A similar case was experienced by PT. Asia Natural Resources Tbk in 2014, which must be delisted by the stock exchange. This was because, following with IDX Number II concerning delisting and relisting, IDX would delisting companies that experience events or conditions that had a significant and negative effect on their survival. In this case, PT. Asia Natural Resources, Tbk. During the first half of 2014, the company did not record sales at all, so it suffered a loss of Rp 357.33 billion.

Learning from these cases, one of the motivations for doing this research was the need to discuss the concept of business continuity from the indicators that underlie a company said going concern not only from the final results in the form of audit opinions. This was because in previous studies going concern measurement only uses audit opinion measurement tools, but in reality, as described in several cases above, the audit opinion could not guarantee a company to be able to survive in the next period.

In Indonesia, there had been many small and medium listed enterprises that experienced a decline in performance due to this economic uncertainty, including PT. Nusa Raya Cipta Tbk decreased profit by $78 \%$ in 2016 . The same thing was experienced by PT. Kimia Farma (Persero) Tbk, which experienced a $30 \%$ decline in profits,
PT. Metrodata Electronics Tbk, which decreased by $45 \%$, and PT. Selamat Sempurna Tbk, which had decreased by $70 \%$. Seeing a large number of small and medium listed enterprises in Indonesia experiencing the impact of economic uncertainty, academics and governments need to think about how the sustainability of their businesses that were undeniable also had a contribution to the country's economy.

In the concept of going concern itself, there were indicators that become the evaluation of a company to be said going concern. These indicators include financial indicators and operational indicators (Tuanakotta, 2016). Financial indicators alone were seen as an appraisal of how the financial condition of the company, whereas the more operational indicators relating to the company's position in the market (Svanberg \& Öhman, 2014). Speaking of financial indicators had many things that affected a company to be said to be able to survive or not go bankrupt. Lyngstadaas \& Berg (2016) stated that companies that had a low liquidity ratio allow for an increased risk of bankruptcy. Lyngstadaas \& Berg (2016) also added that a company's cash flow was a basic prerequisite for enabling future growth. Besides Lyngstadaas \& Berg (2016), Iqbal et al., (2014) also provided another factor, which was an indication of a company's going concern that was looking at the profitability of the company. In addition, Tuanakotta (2016) also stated that financial indicators also include operational gains or losses, indications of support from creditors, and so on. The next indicator was the operational indicator that could be assessed from market share, main suppliers, management team, and employee loyalty (Tuanakotta, 2016).

Santosa \& Wedari (2007) conducted a study on the prediction of factors that influence going concern opinion, and the results stated that the factors affecting a company would continue in the next period where the financial condition, previous year's audit opinion, and company size. 
Furthermore, Koh \& Low (2004) conducted a study to test the predictions of going concern companies in Singapore and stated that companies that could continue to live were companies that could to manage the company's working capital well.

In this study, working capital management was chosen as one of the variables that influenced the sustainability of small and medium listed enterprises in Indonesia. This was because of several factors mentioned earlier Tuanakotta (2016) stated that financial condition was not a variable that affects business continuity but was an indicator for an auditor to assess the business continuity of a company. In addition, in times of economic uncertainty, such as what was happening in Indonesia today, challenges that must be faced by companies were related to the availability of capital. This supports the statement of Ramiah et al., (2014) that poor working capital management would result in financial distress within the company. The statement was also supported by further research, which stated that effective working capital management was proven to increase company profitability without causing liquidity problems (Yunos et al., 2015).

Working capital management was one of the functions of accounting, where the accounting function itself was as a provider of financial information. In the process, working capital management was a series of calculations performed using financial information in the form of working capital data, namely accounts receivable, inventory, and corporate debt generated by the accounting function. Without recording and reporting done in accounting, the company could not know the amount of working capital owned by the company and could not be assessed sooner or later on the company's cash conversion cycle.

Research related to the influence of working capital management on profitability had also been conducted by García-Teruel \&
Martínez-Solano (2005) in small and mediumsized businesses (SMEs) in Spain. This research reveals that SME must be able to minimize the cash conversion cycle (CCC), which was a measure of working capital management to increase profitability. The cash conversion cycle itself was a formula used to calculate how fast a company could convert assets into cash. CCC was considered as an appropriate measurement tool for working capital management because CCC calculation combines all components of working capital consisting of accounts receivable management, inventory management, and also accounts payable management. By calculating the CCC, it would be known how the management or the company's ability to manage current assets owned and maintain cash in the company.

Results were in line with the results of research conducted by Almarazi (2014); Yazdanfar \& Ohman (2014); and Iqbal et al. (2014), namely the cash conversion cycle had a negative effect on the profitability of a company. However, the results of research from Sharma \& Kumar (2011) and Padachi (2006) stated the opposite, namely, the cash conversion cycle had a positive effect on company profitability. This happens, because a large number of accounts receivable values could prolong or increase the CCC figure. However, the provision of receivables was a way for companies to increase their sales.

In addition, Singh et al. (2017) precisely stated that the relationship between cash conversion cycle and profitability was not found to be significant in the case of mid-level companies. In the study, Singh et al. (2017) explained that one of the reasons that might underlie the insignificance of CCC's relationship with profitability was that most SMEs did not had sufficient technology and knowledge related to working capital management or working capital management. In Indonesia alone, it had been tested how the influence of working capital 
management on the profitability of manufacturing companies on the IDX while research for small and medium-sized enterprises was still not there. Therefore, this study would try to test whether working capital management affects the sustainability of the business of small and medium listed enterprises in Indonesia.

As explained prior that it was in times of economic uncertainty like present many challenges must be faced by companies in maintaining their businesses. Rashid (2014) conducted a study related to the decision to finance a company with external capital. The results showed that when risks due to economic uncertainty increase, companies tent to reduce bond issuance. This was because the use of large external capital was felt to burden the company in carrying out its operations.

In addition, Rashid (2014) also revealed that debt could increase the probability of bankruptcy. This finding also supported the idea that debt made companies more exposed to macroeconomic risks, so companies tend to choose to had less debt in their capital structure during the current unstable and uncertain economic conditions. A possible explanation for this finding was that an uncertain macroeconomic environment could worsen a company's potential cash flow, which increased financial pressures for the company.

In contrast to Rashid (2014); Maulana \& Safa (2017) actually saw debt or external capital from a different perspective. In his research, Maulana \& Safa (2017) stated that external capital could actually help corporate funding. The increase in capital in the company, the company could carry out various developments such as increasing sales, opening branches, and so on, which could increase profitability and the company's competitiveness in the market. This was the basis for researchers to take external capital as an independent variable that affects the business continuity of small and medium listed enterprises. Basically, capital was divided into internal and external capital. However, in this study, external capital was chosen as an independent variable because internal capital did not cause companies to had additional obligations such as paying interest and others.

This study sought to examine the effect of working capital management and external capital on the business continuity of small and medium listed enterprises in Indonesia. To achieve this, companies that were included in the Pefindo 25 index were used as samples. The results of this study were expected to be beneficial for small and medium listed enterprises in Indonesia and also for potential investors who would invest their capital. This means that investors could find out how to assess which companies had the possibility of going concern and should be chosen as a place to invest. In addition, this research could also be a reference for small and medium listed enterprises, especially related to how they could prepare and maintain the sustainability of their businesses even in times of economic uncertainty.

\section{LITERATURE REVIEW}

\section{Trade-off Theory}

Trade-off theory was a capital structure theory in which there was a statement that a company that had absolutely no debt was a bad company, but using debt capital or loans for the overall operations of the company was also a very bad thing (Brigham \& Houston, 2007). In the tradeoff theory, there was also a statement that basically the company exchanges tax benefits from the use of debt with a new burden that was the potential for bankruptcy. Therefore, the best decision was to consider the selection of funding instruments.

The trade-off theory assumes that there were tax benefits on the use of debt, so the company would increase debt funding to a certain level in order to increase the value of the company. The trade of theory, which was opened 
by Modigliani \& Miller (1963), actually suggested that companies should continue to increase the value of their debt to increase the value of the company from the tax benefits it causes. However, the reality was that the higher the company's debt, the higher the bankruptcy risk faced by the company (Brigham \& Ehrhardt, 2011). This was caused by an increase in the burden that must be borne by the company when deciding to increase capital with alternative debt. Then the essence was the company must be able to balance the number of benefits obtained with sacrifice or costs incurred due to the use of debt itself. That was why the trade-off theory opposes the use of $100 \%$ debt in financing the company's operations.

\section{Pecking Order Theory}

Basically, in theory, it was stated that there was a pecking order in the use of capital. This theory also explains that companies tend to prioritize internal equity funding (retained earnings) compared to external equity funding (issuance of new shares). Myers (1984) states that companies prefer to use internal equity first, then if the company requires external funding, the company would first choose debt before external equity. In his theory, Myers (1984) revealed that companies that depend on internal funding could maximize the wealth of shareholders. This happened because the old shareholders were not interested in the issuance of new shares, which would normally result in a decline in the share price of the company in the capital market.

The main problem in the capital structure decision, according to Myers (1984) in pecking order theory, was actually the existence of asymmetric information between investors and company managers related to the internal conditions of the company and the view that manager was considered to be more favorable to the old shareholders. These problems make the sequence of company funding begins with internal funding, and then the last new debt was share.

\section{Signaling Theory}

Signaling theory or signaling theory was a theory that emphasizes the importance of information released by a company for investment decisions by parties outside the company. Miller \& Whiting (2005) stated that an organization would try to give signals in the form of good news to potential investors through disclosures in financial statements. Information becomes something that was very important for investors and business people because the information was essentially a record, information, or representations associated with the state of a company in the past, the present, and how the business continuity of the company in the future would come.

According to Leland \& Pyle (1977), a signal was an action taken by an old owner to communicate the information he had to the investor. This signal was in the form of information about everything that had been done by management to realize the wishes of the owner of the company. Through disclosure in the statement of financial company could provide some financial information that could be used by investors to assess how the financial condition of the company, the company's position in the competitive market, and what were the prospects of the company in the future would come.

Working capital was a key and also a key component in a company's operational activities (Pais \& Gama, 2015). Without adequate working capital, companies would certainly not be able to carry out their operational activities (Yunos et al., 2015). Once the importance of working capital in a company was even likened to Padachi (2006) as a vein, making a company need to carry out effective management. Based on several studies that had been conducted, they were showing that poor working capital management could cause financial distress that would eventually lead to the bankruptcy of Koh \& Low (2004); Ramiah et al. (2014); and Yunos et al. (2015). 
Following up on research on the importance of working capital management concerning to business continuity, García-Teruel \& MartínezSolano (2005); Almarazi (2014); and Yunos et al. (2015) stated that the cash conversion cycle as a measure of working capital management had a negative effect on company profitability. This means that the smaller the cash conversion cycle number, the more effective working capital management the company does. When working capital could be managed effectively, it means that companies could quickly convert their cash into inventories, which were then quickly converted into cashback.

Sharma \& Kumar (2011) and Padachi (2006) conducted a similar study of working capital management on profitability. But the results of the study showed different things that CCC had a positive effect on company profitability. The explanation was that the greater the number of accounts receivable, the greater the value of CCC. However, the provision of accounts receivable itself was the company's step in increasing sales, which results in profitability. Singh et al. (2017) also showed a different result that $\mathrm{CCC}$ did not significantly influence profitability in the case of mediumsized businesses. This happens because the majority of SMEs do not yet had the technology and capabilities related to working capital management. In addition to influencing profitability, Martono (2002) stated that when companies had enough working capital, an increase in various things to face increasingly competitive market competition could also continue. Besides that, Setyanto \& Permatasari (2014) stated that proper working capital management affects the value of a company.

From the description above, then a link could be drawn that there was continuity between working capital management to various businesses or indicators of a company said going concern, then the hypothesis could be formulated as follows:
$\mathbf{H}_{1}$ : Working capital management take effect on the business continuity of small and medium listed enterprises in Indonesia

In times of economic uncertainty, the thing most needed by companies to deal with various risks was the availability of capital (Ramiah et al., 2014). Own capital could come from internal or external. The decision to choose an alternative source of capital was influenced by how the obligations or risks must be borne by the company after using the source of capital (Ross et al., 2015). Cifuentes et al. (2005) and Rashid (2014) stated that debt was a source of capital that had a high risk to the life of the company. This risk occurs because when there was an increase in external capital, the impact was that the company gets an additional burden, both interest expense and principal loan payments (Santosa \& Wedari, 2007). The increase in debt was accompanied by this burden if, without offset by the availability of adequate current assets, it would expose the company to liquidity problems. When liquidity problems occur, according to Ramiah et al. (2014), the probability of the company going bankrupt that threatens business continuity was increasing.

In contrast to the description above, Maulana \& Shafa (2017) actually saw the impact of external capital from a different side. In his research, they stated that the presence of external capital would affect the company's profitability. This happens because, with the availability of capital for the company, the company could increase sales by increasing promotions or others so that profitability increases and business continuity could be maintained. In addition, according to Susanti \& Hidayat (2015), external capital had a much higher risk compared to internal capital. The rationale was that the higher the risk of a company, the higher the level of profitability expected in return for high levels of risk, and conversely, the lower the risk of the company, the lower the expected profitability in return for lower risk. From this explanation, the hypotheses that could be formulated were: 
$\mathbf{H}_{2}$ : External capital takes effect on the business continuity of small and medium listed enterprises in Indonesia.

\section{RESEARCH METHODS}

Samples taken in this study were small and medium listed enterprises in Indonesia, which were included in the Pefindo-25 index with the time of the study began in 2009-2016. The Pefindo-25 index itself ranks twice each year, in January and July. The technique used in selecting data included in the research was using purposive sampling. In this technique, specified criteria that must be met in the sampling. The criteria of the company in question were:

1. The company was included in the Pefindo25 index in 2016 at the announcement of the index ranking of semester II

2. The company was included in the Pefindo25 index at the time of the study

The criteria were intended so that the data used were financial statements that had been audited and produced as many as 76 units of analysis.

\section{Research Variables and Operational Definitions}

The dependent variable used in this study was the business continuity of small and medium listed enterprises. Based on Indonesian Generally Accepted Accounting Principles, it had been stated that a company's financial statements must be prepared based on the assumption of business continuity (going concern). Going concern or business continuity was an assumption that every company was established to survive (Santosa \& Wedari, 2007).

Going concern assessment would be conducted to see how the company's ability to continue in the future. According to Tuanakotta (2016), going concern assessment could be measured using financial and operational indicators. From the indicators described in the literature review section, several indicators were not used because they couldnot be quantified.
Therefore for going concern assessment could be seen in Figure 1.

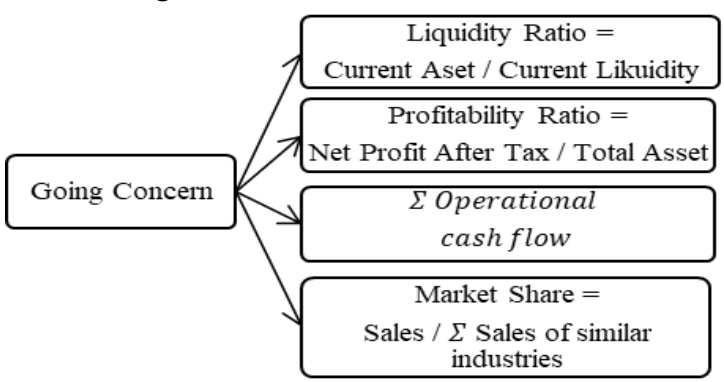

Figure 1. Proxy Going Concern

From the results of the proxy calculation in Figure 1, four values would be obtained, which would then be tested together with the independent variables, namely working capital management and external capital. In this study, the independent variables used were working capital management and external capital.

a. Working Capital Management

Working capital management was a form of management carried out by companies related to how companies control current assets and current liabilities owned by Yunos et al. (2015). As it relates to assets and also current liabilities so that capital management work was something that was very important in the company. In measuring work capital management, Yunos et al. (2015) stated that the most appropriate measurement tool was the cash conversion cycle (CCC). CCC of in a language Indonesia said as the cash conversion cycle was a formula used to how the ability of a company to change the existing cash flows to be something to sell and then re-generate cash for the company. Basically, the CCC calculation consists of inventory turnover, accounts receivable turnover, and also debt turnover (Yunos et al., 2015). CCC formula:

$$
\mathrm{CCC}=\mathrm{DIO}+\mathrm{DSO}-\mathrm{DPO}
$$

Where:

CCC: Cash Conversion Cycle DIO: Days Inventory Outstanding (average inventory/COGS per day) 
DSO: Days Sales Outstanding

(average receivables/income per day

DPO: Days Payable Outstanding (average debt/COGS per day)

b. External Capital

External capital was capital obtained by companies from third parties outside the company, such as banks, suppliers, and others (Hadianto, 2010). Basically, external capital consists of total funding owned by the company. Funding itself was a way carried out by a company to obtain funds to cover company needs. Furthermore, to find out the value of a company's external capital, it could be seen from the total of all debts that were included in the category of external capital, so if it was written mathematically it was:

$$
\mathrm{ME}=\sum \text { Short-term Debt }+\sum \text { Long-term }
$$

where

ME: External capital

$\sum$ Short- term debt: Total short-term debt

$\sum$ Long -term debt: Total of all long-

term debt

This study was conducted to determine the relationship between several independent variables with multiple dependent variables that were used canonical correlation analysis (canonical correlation). In this study, the variables to be tested were working capital management $\left(\mathrm{X}_{1}\right)$, external capital $\left(\mathrm{X}_{2}\right)$, and business continuity, where business continuity was represented by four proxies, namely liquidity ratios, profitability ratios, operational cash flow, and market share.

In the canonical correlation analysis, the equation model formed in this study was as follows:

$$
\mathrm{CR}_{i t}+\mathrm{ROA}_{i t}+\mathrm{AO}_{i t}+\mathrm{PP}_{i t}=\mathrm{CCC}_{i t}+\mathrm{ME}_{i t}+e_{i t}
$$

where

$\mathrm{CR}_{i t}$ : Liquidity ratio

$\mathrm{ROA}_{i t}$ : Profitability ratio
$\mathrm{AO}_{i t} \quad$ : Operating cash flow

$\mathrm{PP}_{i t} \quad$ : Market share

$\mathrm{CCC}_{i t}$ : Working capital management

$\mathrm{ME}_{i t} \quad$ : External capital

\section{RESULT}

The following were the results of descriptive statistics in this study (Table 1).

Table 1. Descriptive Statistic

\begin{tabular}{lccccc}
\hline & $\mathrm{N}$ & $\begin{array}{c}\text { Mini } \\
\text { mum }\end{array}$ & $\begin{array}{c}\text { Maxim } \\
\text { um }\end{array}$ & Mean & $\begin{array}{c}\text { Std. } \\
\text { Deviati } \\
\text { on }\end{array}$ \\
\hline CCC & 76 & -82.48 & 956.58 & 103.17 & 170.90 \\
ME & 76 & 22.42 & 28.28 & 25.92 & 1.46 \\
CR & 76 & .91 & 11.09 & 2.92 & 2.59 \\
ROA & 76 & -.02 & .42 & .12 & .078 \\
AO & 76 & -26.43 & 28.56 & 20.15 & 16.76 \\
PP & 76 & .01 & 1.00 & .16 & .26 \\
\hline Valid & & & & & \\
N & 76 & & & & \\
(listw & & & & & \\
ise) & & & & & \\
\hline Source: & & & & & \\
\end{tabular}

Source: by author

a. Formation of Canonical Functions

Basically, the canonical correlation analysis would form two canonical functions. This canonical function was a function that was formulated to accommodate the relationship between the variables tested (Sarwono, 2006). This test was carried out using Eigenvalues and Canonical Correlations and the following Dimension Reduction Analysis:

Table 2. Correlation Test Clinical Function Eigenvalues and Canonical Correlations

\begin{tabular}{cccccc}
\hline $\begin{array}{c}\text { Root } \\
\text { No }\end{array}$ & $\begin{array}{c}\text { Eigen- } \\
\text { value }\end{array}$ & Pot & $\begin{array}{c}\text { Cum. } \\
\text { Pot }\end{array}$ & $\begin{array}{c}\text { Canon } \\
\text { Cor }\end{array}$ & $\begin{array}{c}\text { Sq. } \\
\text { Cor }\end{array}$ \\
\hline $\mathbf{1}$ & 1.81950 & 93.60666 & 93.60666 & .80332 & .64533 \\
\hline $\mathbf{2}$ & .12427 & 6.39334 & 100.00000 & .33247 & .11054 \\
\hline
\end{tabular}

Based on Table 2 above, it could be seen that from 2 independent variables (working capital management and external capital) and four dependent variables (liquidity ratio, profitability ratio, operational cash flow, and market share) formed into two canonical functions, namely Root No. 1 and Root No.2. For Root No. 1 or the first canonical function, 
the magnitude of the correlation was 0.80332, as seen from the Canon Cor values above. As for Root No. 2 or the second canonical function, the magnitude of the correlation was 0.33247 . If analyzed from the magnitude of the correlation, it was stated that the first canonical function was greater than the second canonical function. However, determining which canonical functions would be used must also look at the significance value of each canonical function in Table 3.

b. Test the Significance of Variable Relationships

The significance of the relationship between variables could be seen using the Sig of F numbers through the Wilk's Lambda Test. In this test, the criteria used was if the significance value smaller than $\alpha(0.05)$, then $\mathrm{H}_{0}$ was rejected, and $\mathrm{H}_{1}$ was not rejected. Conversely, if the value of significance was greater than $\alpha(0.05)$ then $\mathrm{H}_{0}$ was not rejected or the relationship between variables was not significant.

Table 3. Test the Significance of Variable Relationships

Multivariate Tests of Significance $(\mathrm{S}=2$, $\mathrm{M}=1 / 2, \mathrm{~N}=18$ )

\begin{tabular}{llcccc}
\hline $\begin{array}{c}\text { Test } \\
\text { Name }\end{array}$ & Value & $\begin{array}{c}\text { Approx } \\
\text { F }\end{array}$ & $\begin{array}{c}\text { Hypoth } \\
\text { Df }\end{array}$ & $\begin{array}{c}\text { Error } \\
\text { DF }\end{array}$ & $\begin{array}{c}\text { Sig. } \\
\text { of F }\end{array}$ \\
\hline Pillais & .75586 & 5.92351 & 8.00 & 78.00 & .000 \\
\hline Hotellinga & 1.94377 & 8.98995 & 8.00 & 74.00 & .000 \\
\hline Wilks & .31547 & 7.41397 & 8.00 & 76.00 & .000 \\
\hline Roys & .64533 & & & \\
\hline Note.. F statistic for WILKS' Lambda is exact & &
\end{tabular}

The significance test results using Wilk's Lambda in Table 3 showed that the Sig of $F$ values in both the Test of Pillais, Hotellings, Wilks and Roys all had a value of 0.000 . Due to the significance value smaller than $\alpha(0.05)$, the conclusions were formulated was $\mathrm{H}_{0}$ was rejected, and $\mathrm{H}_{1}$ was not rejected. This shows that the management of working capital and external capital influences the business continuity of small and medium listed enterprises.

Table 4. Signification Test of Colonic Function

Dimension Reduction Analysis

\begin{tabular}{lccccc}
\hline Roots & $\begin{array}{c}\text { Wilks } \\
\text { L. }\end{array}$ & F & $\begin{array}{c}\text { Hypoth. } \\
\text { DF }\end{array}$ & $\begin{array}{c}\text { Error } \\
\text { DF }\end{array}$ & $\begin{array}{c}\text { Sig. } \\
\text { Of } \mathbf{~ F}\end{array}$ \\
\hline $\mathbf{1}$ to 2 & .31547 & 7.41397 & 8.00 & 76.00 & .000 \\
\hline $\mathbf{2}$ to 2 & .88946 & 1.61554 & 3.00 & 39.00 & .201 \\
\hline
\end{tabular}

By looking at the Dimension Reduction Analysis shown in Table 4, the significance value of the first canonical function (Root No.1) was 0.000 less than $\alpha(0.05)$. While the significance value of the second canonical function (Root No.2) was 0.201 greater than $\alpha(0.05)$, by predetermined criteria, that only functions that had a significance value $<\alpha$ indicate a significant relationship between groups of independent variables and groups of dependent variables so that only the first canonical function (Root No.1) would be processed further. The formation of canonical functions with a significance value of less than $\alpha(0.05)$ also indicates that the conclusions of the next test, the Wilk's Lambda test, would be used on the two independent variables formulated.

c. Canonical Variates Measurement Canonical variate was a collection of several variables that form a variate (Ghozali, 2013). In principle, this analysis was intended to determine whether all independent variables in the canonical variate were strictly related to the dependent variate. The relationship was seen from the magnitude of the correlation of each independent variable with its variance. The measurement of canonical variates in this study was carried out with the canonical loading test shown in Table 5. 
Table 5. Canonical Loading Discussion Correlations between Covariates and canonical variables CAN.VAR.

\begin{tabular}{lcc}
\hline Covariate & $\mathbf{1}$ & $\mathbf{2}$ \\
\hline CCC & -.42381 & .90575 \\
\hline ME & .88486 & .46585 \\
\hline
\end{tabular}

a. The Effect of Working Capital Management on the Sustainability of Small and Medium Businesses in Indonesia

The first independent variable formulated in this study was working capital management that was measured using the value of the cash conversion cycle (CCC). In the CCC calculation itself, there were three components used, namely days inventory outstanding, days sales outstanding, and days payable outstanding. In principle, the higher the CCC value, the worse the working capital management of a company. Conversely, the smaller the CCC value, the better the working capital management of a company.

A series of test results show that working capital management represented by the cash conversion cycle had a weak influence on the sustainability of small and medium listed enterprises. Because the influence exerted was weak, it could be stated that whether or not the working capital management of a company does not guarantee the company to remain going concern. The weak influence of working capital management on the business continuity of small and medium listed enterprises in Indonesia could occur because sometimes the company prioritizes inventory turnover to maximize sales rather than receivable turnover, whereas according to Baker et al. (2017) accounts receivable management was the most important component in working capital management. Even though it was weak, but based on the results of working capital management testing, it had a negative effect on the business continuity of small and medium listed enterprises in Indonesia. This means that the better the working capital management of a company, the higher the business continuity of the company even though the probability was small.

The size of the CCC depends on how quickly the company was able to sell its inventory, collect accounts receivable, and delay debt payments to maintain cash in the company. With a fast cash conversion cycle, it means that the existing inventory in the company was able to sell quickly, so it does not cause a build-up of inventory, which results in losses and additional costs for the company. In addition, a fast cash conversion cycle means that the company was able to collect receivables quickly, thereby reducing the risk of uncollectible accounts. This makes the company does not get an additional burden in the form of receivables loss.

The research result was consistent with the results of García-Teruel and Martinez-Solano (2005); Almarazi (2014); Yazdanfar \& Öhman (2014); and Iqbal et al. (2014) which showed that to continue to survive and increase profitability, companies must be able to minimize or accelerate the cash conversion cycle they had as it was known that cash was a type of asset that was very liquid compared to other assets. By having enough cash, the company would be able to pay off every debt it had so that it was not disturbed by liquidity problems that were indicative of bankruptcy. In addition, with sufficient cash, the company could continue to develop well through increasing sales, new product innovations, or other forms of expansion.

For example, PT Ace Hardware Indonesia Tbk in 2015 had a cash conversion cycle of 190.84 days. The amount was long enough for a company to be able to receive back the cash that had been used so that it 
was said that the company's working capital management was not proper or even tends to be bad. Evidence, based on the long cash conversion cycle, the liquidity ratio of PT Ace Hardware Indonesia, Tbk., reached 1.79 times, which indicates that the company's ability to pay off short-term debt was not good. In addition, reduced working capital management also had an impact on the company's sales capability, which was only able to dominate the market in similar industries by $2.63 \%$. In contrast, PT. Catur Sentosa Adiprana, Tbk., which belongs to the same type of industry, namely retail trade, which had a much faster cash conversion cycle, which was 41.87 days, was able to dominate the market by $4.04 \%$. This could be due to the expansion was undertaken by PT Catur Sentosa Adiprana Tbk, namely, opening the 21st Mitra-10 outlet in Palembang in 2015. In addition, the company's ability to repay its short-term debt was also outstanding at 0.09 times a year 2015.

As explained above, the results of the study indicate that working capital management had a negative effect on the business continuity of small and medium listed enterprises. This means that a company must be able to accelerate the company's cash conversion cycle, as it was known that cash was the most liquid and most crucial asset in a company's life (Warren et al., 2014). Cash was the main source used to finance the company's operations. A lousy cash cycle would hamper the company's operations and ultimately had an impact on the company's ability to maintain business continuity. The results of this study also support the tradeoff theory, which states that companies must be able to balance the benefits of using debt with the risk of financial difficulties because by maintaining cash in the company and delaying debt payments would had an impact on company liquidity.

b. The Influence of External Capital on the Sustainability of Small and Medium Enterprises in Indonesia

The second independent variable used in this study was external capital. The intended external capital was the total funding debt owed by the company. The results of this study indicate that external capital had a strong positive influence on the sustainability of small and medium listed enterprises in Indonesia, which means that the higher the external capital owned by the company, the higher the business continuity of the company. This was because this research was conducted at small and medium level enterprises, where this company was a type of company that still needs a lot of capital to be able to compete with a number of large companies in Indonesia.

The results of this study were consistent with statements made by Maulana \& Safa (2017) that external capital was a source of capital that could help companies to develop business activities and increase company profitability. With the availability of capital in the company, the company could increase sales by increasing promotions, opening new branches, and so on. With various things that could be done, it could increase profitability so that business continuity could be maintained. Besides, in terms of sales, by having external capital, one of which was in the form of financial leases, the company could had new machinery or technology without having enough cash. With the existence of new technology, the company was able to compete in the competition amidst the times.

For example, PT Link Net Tbk in 2016 increased the amount of external capital in the form of a finance lease debt of $\mathrm{Rp}$ 
130,307,000,000. PT Link Net Tbk itself was a company engaged in the field of internet services, telephone, and others. The increase in external capital was intended to improve the quality of services provided by the company. It was proven that in 2016, the company's sales increased by $15 \%$ compared to the previous year. With this significant increase in sales, the company's profitability was able to reach $16.19 \%$. In addition, in 2016, the company was also able to dominate the market by $8.93 \%$, where the company ranked fifth in sales in the types of advertising, printing, and media industries.

In addition, the results of this study were also in line with a trade-off theory and pecking order theory. In trade-off theory explained that debt had tax benefits for companies (Modigliani \& Miller, 1963). With the capital in the form of external capital, the company would incur a number of additional expenses such as interest expenses, coupons, and others. These expenses were types of expenses that could be deducted from taxable profits, so the amount of tax that must be paid by the company could be reduced. The trade-off theory also explained that companies that had no debt at all were bad companies (Brigham \& Houston, 2007). The trade-off theory itself had an assumption that the company would continue to add external funding to a certain level to get more and more tax benefits.

Furthermore, the results of this study were also following with the pecking order theory by Myers (1984), which revealed that debt was a better source of funding compared to the issuance of shares. Myers (1984) stated that the issuance of new shares was the last alternative in corporate funding. This was because the issuance of new shares was a sign for potential investors and told shareholders that the company's current condition and future prospects were in bad condition. In addition, the cost of issuing new shares was considered higher than the cost of issuing debt.

\section{CONCLUSIONS}

Based on the results of tests and analysis conducted, it could be concluded that:

1. Working capital management represented by a cash conversion cycle had a negative effect on the sustainability of small and mediumsized issuers in Indonesia. This was because when the company's working capital management was proper, it means that the company was able to sell its inventory quickly so that it does not cause an accumulation of inventory that causes losses and additional burdens for the company. Then, a fast cash conversion cycle means that the company was able to collect receivables quickly, thereby minimizing the burden of loss on receivables. In addition, cash was the most liquid and vital asset to the company. With sufficient cash, the company's operational activities would not be disrupted, all obligations could be paid off on time, and the company could undertake various business developments such as increasing sales, product innovation or other forms of expansion so that the company was able to remain in competition and be able to maintain its sustainability (going concern).

2. External capital had a positive effect on the sustainability of small and medium listed enterprises in Indonesia. This was because small and medium listed enterprises in Indonesia were types of businesses that still require a lot of capital to be able to compete with several large companies in Indonesia. External capital itself was a source of additional capital that could be used to develop businesses such as increasing sales, developing new technologies, opening new branches, and so on. This business 
development could increase the profitability and market share of the company so that business continuity could be maintained.

Based on the results of the research that had been done, the suggestions that could be given were:

a. For further researchers

For further researchers who will conduct research on the topic of business continuity (going concern) could use the proxy used in this study, namely liquidity ratios, profitability ratios, operational cash flow, and market share. In an effort to achieve measurement perfection, the next researcher was expected to be able to use all proxies of business continuity, which include financial and operational indicators. Financial indicators were the main financial ratios, net liability positions, loans that were near maturity, operational cash flow, indications of support from creditors, ability to meet loan conditions, and operational profit or loss, while operational indicators include market share, key suppliers, management and loyalty of employees.

b. For small and medium listed enterprises

Small and medium-sized issuers in Indonesia are expected to be able to accelerate the company's cash conversion cycle to improve working capital management so as to improve the sustainability of the company's business. Then, small and medium issuers in Indonesia were expected to consider external funding as an alternative capital to increase competitiveness in the market.

c. For investors

The advice could be given to investors was expected that investors not only see the profit of a firm to assess the company worthy of investment but also assess the sustainability expectations of the company's business through financial indicators and operational indicators that were used in this study.

\section{REFERENCES}

Almarazi, A. A. (2014). The Relationship Between Working Capital Management And Profitability: Evidence from Saudi Cement Companies. British Journal of Economics, Management \& Trade, 4(1), 146-157.

Baker, H. K., Kumar, S., Colombage, S., \& Singh, H. P. (2017). Working Capital Management Practices in India: Survey Evidence. Managerial Finance, 43(3), 331353. https://doi.org/10.1108/MF-07-20160186

Brigham, E. F., \& Ehrhardt, M. C. (2011). Financial Management: Theory and Practice. (J. W. Calhoun, Ed.) (Thirteen). USA: Nelson Education Ltd.

Brigham, E. F., \& Joel F. H. (2007). Fundamentals of Financial Management. Eleventh Edition. USA: Thomson Higher Education

Cifuentes, R., Ferrucci, G., \& Shin, H. S. (2005). Liquidity Risk and Contagion. Journal of the European Economic Association, 3(2/3), 556-566.

https://doi.org/10.1162/jeea.2005.3.2-3.556

Didonet, S., Simmons, G., Díaz-Villavicencio, G., \& Palmer, M. (2012). The Relationship Between Small Business Market Orientation and Environmental Uncertainty. Marketing Intelligence \& Planning, 30(7), 757-779.

https://doi.org/10.1108/02634501211273841

García-Teruel, P. J., \& Martínez-Solano, P. (2005). Effects of Working Capital Management on SME Profitability. International Journal of Managerial Finance, 3(2), 164-177.

https://doi.org/10.1108/17439130710738718

Ghozali, I. (2013). Multivariate Analysis Application with IBM SPSS 23. Semarang Program: Diponegoro University Publisher Agency.

Hadianto, B. (2010). Effect of Asset Structure, Company Size, and Profitability on the Capital Structure of Issuers in the Telecommunications Sector 2000-2006: A Pecking Order Hypothesis Testing. Journal of Management, 7 (2), 14-29. 
Iqbal, N., Ahmad, N., \& Riaz, Z. (2014). The Relationship between Working Capital Management and Profitability: Evidence from Pakistan. International Letters of Social and Humanistic Sciences, 20, 14-25. https://doi.org/10.18052/www.scipress.com/ ILSHS. 20.14

Koh, H. C., \& Low, C. K. (2004). Going Concern Prediction Using Data Mining Techniques. Managerial Auditing Journal, 19(3), 462-476. https://doi.org/10.1108/02686900410524436

Leland, H. E., \& Pyle, D. H. (1977). Informational Asymmetries Financial Structure, and Financial Intermediation. The Journal of Finance, 32(2), 371. https://doi.org/10.2307/2326770

Lyngstadaas, H., \& Berg, T. (2016). Working Capital Management: Evidence from Norway. International Journal of Managerial Finance, 12(3), 295-313. https://doi.org/10.1108/IJMF-01-2016-0012

Martono, C. (2002). Analysis of the Effect of Industry Profitability, Weighted Financial Leverage Ratio and Weighted Capital Intensity and Market Share Against "Roa" and "Roe" Go-Public Manufacturing Companies in Indonesia. Journal of Akuntansi and Keuangan, 4 (2), 126-140.

Maulana, Z., \& Safa, A. F. (2017). The Effect of Short-term Debt and Long-term Debt on Profitability at PT. Bank Mandiri Tbk. Journal of Economic Accounting Research (JENSI), 1 (1), 44-48.

Miller, J. C., \& Whiting, R. H. (2005). Voluntary Disclosure of Intellectual Capital and The "Hidden Value". Journal of Economic Literature Classification, 41, 1-30.

Modigliani, F., \& H.Miller, M. (1963). Corporate Income Taxes and the Cost of Capital: A Correction. The American Economic Review, 53(3), 433-443.

Moss, J. D., \& Stine, B. (1993). Cash Conversion Cycle and Firm Size: a Study of Retail Firms. Managerial Finance, 19(8), 25-34. https://doi.org/10.1108/eb013739

Myers, S. C. (1984). The Capital Structure Puzzle. Journal of Finance, 39.
Öhman, P., \& Yazdanfar, D. (2017). Short- and Long-term Debt Determinants in Swedish SMEs. Review of Accounting and Finance, 16(1),106-124. https://doi.org/10.1108/RAF-08-2015-0118

Padachi, K. (2006). Trends in Working Capital Management and its Impact on Firms' Performance: An Analysis of Mauritian Small Manufacturing Firms. International Review of Business Research Papers, 2(2), 45-58.

Pais, M. A., \& Gama, P. M. (2015). Working Capital Management and SMEs Profitability: Portuguese Evidence. International Journal of Managerial Finance, 11(3), 341-358. https://doi.org/10.1108/IJMF-11-2014-0170

Ramiah, V., Zhao, Y., \& Moosa, I. (2014). Working Capital Management during The Global Financial Crisis: The Australian Experience. Qualitative Research in Financial Markets, 6(3), 332-351. https://doi.org/10.1108/QRFM-09-20120026

Rashid, A. (2014). Firm External Financing Decisions: Explaining the Role of Risks. Managerial Finance, 40(1), 97-116. https://doi.org/10.1108/MF-02-2013-0049

Ross, S. A., Westerfield, R. W., Jordan, B. D., Lim, J., \& Tan, R. (2015). Introduction to Corporate Finance. Book 1. Jakarta: Salemba Empat.

Santosa, A. F., \& Wedari, L. K. (2007). Analysis of Factors Affecting the Tendency of Going Concern Audit Opinion. Journal of UNIKA

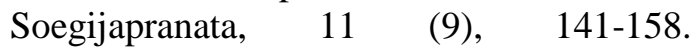
https://doi.org/10.1017/CBO978110741532 4.004

Sari, A. M. (2014). Going Concern Audit Opinion: Study Based on Financial and Non-Financial Factors in Manufacturing Companies Registered in Bei 2011-2013. Journal of Chemical Information and Modeling, 53 (9), 1689-1699. https://doi.org/10.1017/CBO978110741532 4.004 
Sarwono, J. (2006). Quick and Easy Guide to SPSS 14. Edition 1. Yogyakarta: ANDISetiawan, Budi. (2015). Practical Techniques of Analysis of Social and Business Research Data with SPSS. Yogyakarta: ANDI

Setyanto, A. D., \& Permatasari, I. (2014). Working Capital Management and Its Impact on Company Value with Corporate Governance as a Moderating Variable. AKRUAL: Jurnal Akuntansi, 6 (1), 66-82. http://dx.doi.org/10.26740/jaj.v6n1

Sharma, A. K., \& Kumar, S. (2011). Effect of Working Capital Management on Firm Profitability: Empirical Evidence from India. Global Business Review, 12(1), 159173. https://doi.org/10.1177/097215091001200110

Singh, H. P., Kumar, S., \& Colombage, S. (2017). Working Capital Management and Firm Profitability: A Meta-Analysis. Qualitative Research in Financial Markets, 9(1), 34-47. https://doi.org/10.1108/QRFM06-2016-0018
Susanti, A., \& Hidayat, I. (2015). Effect of Debt and Own Capital Against Profitability. Jurnal Ilmu Dan Riset Manajemen, 4(11).

Svanberg, J., \& Öhman, P. (2014). Lost Revenues Associated with Going Concern Modified Opinions in the Swedish Audit Market. Journal of Applied Accounting Research, 15(2), 197-214. https://doi.org/10.1108/JAAR-11-2012-0077

Tuanakotta, T. M. (2016). Contemporary Audit. Jakarta: Salemba Empat

Warren, C. S., Reeve, J. M., Duchac, J. E., Wahyuni, E. T., \& Amir Abadi Yusuf. (2014). Introduction of accounting. Jakarta: Salemba Empat.

Yazdanfar, D., \& Öhman, P. (2014). The Impact of Cash Conversion Cycle on Firm Profitability. International Journal of Managerial Finance, 10(4), 442-452. https://doi.org/10.1108/IJMF-12-2013-0137

Yunos, R. M., Nazaruddin, N., Ghapar, F. A., Ahmad, S. A., \& Zakaria, N. B. (2015). Working Capital Management in Malaysian Government-linked Companies. Procedia Economics and Finance, 31(15), 573-580. https://doi.org/10.1016/S2212-5671(15)01203-4 